\title{
Preface: The battle for intelligence/re-enchantment of the world
}

The articles in this special issue have a specific history. They emanate from two conferences, 'The re-enchantment of a dis-enchanted world' and 'The battle for intelligence in tertiary education', hosted in the Department of Information Science at the University of Pretoria. These two themes are interconnected and mutually implicated in their impact on each other. Both form part of what should be understood as the mission, aim and goal of higher education - this should be the final focus of university education if education (and not mere training) is still considered part of the task of institutions of higher learning. All the authors involved reflected deeply and seriously on the importance of the pursuit of intelligence and re-enchantment for institutions of higher education and our country to survive.

In publishing the series of articles we hope to contribute to the re-enchantment of a disenchanted world. We aim to do this in a transdisciplinary way, by transcending disciplinary boundaries in significant ways, without risking disciplinary authenticity. The re-enchantment in itself is a tremendous challenge and the battle for intelligence and the struggle against ignorance will be a real but implicit condition. Foolishness, foolhardiness, ignorance and stupidity are the main contributory factors to disenchantment. The articles are efforts from different perspectives to take on this challenge we set for ourselves - firstly by participating in the two conferences and secondly by reworking our papers into publishable articles.

The two conferences were sparked off by the awareness that a desperately disenchanted world has established itself - a world in which it becomes more and more difficult and problematic for humans to lead or live meaningful lives. The single most important, significant and decisive reason for this status of the world is the depletion, degradation, or even loss of human spirituality. The most serious implication of this process of despiritualisation, is the fatal loss of focus on human intelligence in the true sense of this word (as a translation of the Greek word nous) as well as the loss of a world of meaning. Many have the conviction that by attending, with full responsibility, to these different losses in order to regain their decisive importance, may be what is essentially required if we wish to re-enchant the world, to make it more liveable, and to regain the responsible power of intelligent human thought, as its condition, through the re-invention of human spirituality.

The inspiration for this initiative stems from the many colleagues who share in great despair their experiences of the fate of key institutions, among other institutions of tertiary education, in their inability to cope with the real crises in the world and with the appeal to bring about a better world. These experiences of many colleagues, almost in a generalizable sense, are in substantial ways supported and also reinforced by the literature in this regard. It is significant to note how many of these studies are the outcome of the intellectual work of prominent intellectuals world wide - certainly significant names in their areas of specialisation and definitely worth taking cognizance of.

The reinvention of intelligence in tertiary education is a condition for the much desired reenchantment of a disasterfully disenchanted world. The importance for academics to go beyond the generally expected and accepted ways of making a contribution to this (in other words, transcending the status quo) is highlighted and capably articulated and must be emphasised. The necessary transition from creating intelligence to re-enchantment is 
articulated in terms of 're-enchantment through transcendence' (Naidoo). The closely related emphasis on the human spirit as a condition for higher education to flourish and achieve success (Wessels) and the engagement between science and society for the rediscovery of the relevance of science for society and of society for science (Lotriet) is complemented by a significant reflection on the battle for 'scholarly' intelligence, an initiative extensively underplayed in contemporary higher educational institutions (Olivier), as well as by the emphasis on whole brain activity instead of reduced brain activity in the education of students (and lecturers) (De Boer, Du Toit, Bothma). These contributions on intelligence development and cultivation pave the way for a better world, for the re-enchantment of a disenchanted world. Reflecting on the complexity of the situation of disenchantment/reenchantment reveals the difficulties involved in such pursuits and the sincere hope is expressed that the house of man built by the Lord can/may become our glorious and enchanted universe (Pauw). This proposal is amplified by the exploration of the difference between the embracement of the sense of place as a form of enchantment and impersonal space as something representing disenchantment (De Klerk), while the articulation of the history of 'the lived earth' in terms of the disenchanting impact of the turbulent history of water is required to encourage humans to learn to act and interact in concert with nature in order for the re-enchantment of the world to materialise (Tempelhoff). The condition for both the re-invention of intelligence and of the re-enchantment of the world requires a wholehearted compliance with the condition of invention, an inventive spirit and inventiveness, namely the attitude and strategy of multiple, connective intellection in the dealings with the vast problems humans encounter on a daily basis (De Beer).

I wish to sincerely thank the authors for their commitment and dedication to this project and the referees for their thorough and diligent contributions. A special word of appreciation and thanks to Johann Tempelhoff (Editor) and the Editorial Board of the Journal for Transdisciplinary Research in Southern Africa who kindly agreed to the initiative that made this special issue, The Battle for Intelligence/ The re-enchantment of the World, possible.

Fanie de Beer

Special edition editor

University of Pretoria

October 2015 